\title{
Flexible dosing with Darbepoetin alfa for the treatment of chemotherapy-induced anemia
}

\author{
Isabelle Wauters \\ Karin Pat \\ Johan Vansteenkiste \\ Respiratory Oncology Unit \\ (Pulmonology) and Leuven Lung \\ Cancer Group, University Hospital \\ Gasthuisberg, Catholic University, \\ Leuven, Belgium
}

\begin{abstract}
Anemia is frequent in cancer patients with chemotherapy, and has an important negative effect on health-related quality of life (QoL). Darbepoetin alfa belongs to a new class of erythropoietic proteins with a unique molecular structure and interesting properties compared with classic recombinant human erythropoietin. Darbepoetin alfa is effective for chemotherapy-induced anemia when administered once weekly at a dose of $2.25 \mu \mathrm{g} / \mathrm{kg}$, as shown in two large phase III placebo-controlled trials in patients with solid tumors and hematological malignancies. Furthermore, it was safe and well tolerated. More recently attention has been focused on optimizing Darbepoetin alfa therapy. Front-loaded dosing was explored to accelerate the hemoglobin $(\mathrm{Hb})$ response and effect on QoL, but this idea could not be confirmed in a large phase III study. Based on the prolonged half-life of Darbepoetin alfa, administration every 3 weeks was appealing. In a large phase III trial, noninferiority of administration of $500 \mu \mathrm{g}$ every 3 weeks compared with the weekly dosing could be confirmed, both in terms of reduction of red blood cell transfusion, $\mathrm{Hb}$ parameters, and QoL. This schedule is very convenient for patients and caregivers as it allows synchronization of erythropoietic therapy and common chemotherapy schedules. Questions for future study are the optimal iron supplementation strategy and the effect of Darbepoetin alfa on outcome. This article reviews the clinical development of Darbepoetin alfa with emphasis on recent data.

Keywords: Darbepoetin alfa, erythropoietic therapy, anemia, chemotherapy-induced anemia, pharmacokinetics, clinical trials, quality of life
\end{abstract}

\section{Introduction}

Anemia, a frequent problem in patients with cancer, has multiple possible causes. Most cancer patients have anemia related to chronic disease. Other causes are bone marrow invasion, hemolysis, nutritional deficiencies, bleeding caused by the tumor or due to treatment-induced coagulopathy. The occurrence of anemia will also be influenced by the cancer treatment: chemotherapy, especially platinum-containing chemotherapy and radiotherapy; both can induce anemia. Current cancer therapies often include dose-intense combination chemotherapy or combined chemoradiotherapy, resulting in an even more pronounced risk of myelosuppression.

Anemia has important implications for cancer patients. The most common complaint of a patient with anemia is fatigue and this symptom is known to severely reduce quality of life (QoL) (Curt 2000; Curt et al 2000). The treatment of anemia can provide real benefit for the patient improving his QoL and ensuring the best chances for achieving the planned anti-cancer therapy.

For many years transfusion was the only way of treatment for cancer-related anemia. This had several limitations: the risk of an allogeneic blood transfusion on itself, and the temporary effect and benefit for the patient. There also was a delay of anemia treatment as transfusion was usually not given in case of mild or moderate anemia, but only in case of more severe anemia (hemoglobin $[\mathrm{Hb}] \leq 8 \mathrm{~g} / \mathrm{dL}$ ). 
The primary regulator of erythropoiesis is erythropoietin (EPO), a glycoprotein hormone produced in the kidney, stimulated by tissue hypoxia. The EPO gene sequence is known since 1985 (Lin et al 1985). This allowed the development of recombinant human erythropoietin (rHuEPO), offering an alternative to transfusion in anemic patients: first in anemia due to chronic renal disease (Eschbach et al 1987, 1989) and later also in chemotherapy-induced anemia (CIA) (Cascinu et al 1994). At the moment different erythropoietic agents are available: Epoetin alfa (Procrit, Amgen, Thousand Oaks, USA/Ortho Biotech, Bridgewater, USA; Epogen, Amgen, Thousand Oaks, USA; Eprex, Janssen/Cilag, Beerse, Belgium); Epoetin beta (NeoRecormon, Roche, Basel, Switzerland) and Darbepoetin alfa (Aranesp, Amgen, Thousand Oaks, USA).

Recombinant human erythropoietin therapy has well documented clinical benefits, but frequent dosing is required and response rate is variable. Darbepoetin alfa is a new-generation molecule with clear advantages compared with rHuEPO. This article provides an overview of the evidence for the use of Darbepoetin alfa in patients with CIA.

\section{Darbepoetin alfa}

Erythropoietin research demonstrated that the carbohydrate content, more specifically the sialic acid residues, is the determining factor for the in vivo (not in vitro) biological activity. Studies on isolated rHuEPO isoforms showed that molecules with the highest sialic acid content had the longest plasma half-life and the greatest in vivo bioactivity, but a lower receptor affinity (Darling et al 2002). Clearance and not receptor affinity seemed to be the key factor for enhanced in vivo bioactivity. Five amino-acid changes were designed in Darbepoetin alfa compared with rHuEPO. This enabled the addition of 2 new carbohydrate chains at unique sites of the protein backbone, resulting in a total of $5 \mathrm{~N}$-linked carbohydrate chains compared with 3 in rHuEPO. In summary, the new molecule was distinct from epoetin with regard to physical size, molecular weight, carbohydrate, and sialic acid content. Darbepoetin alfa works through interaction with the EPO-receptor to promote proliferation, survival, and differentiation of hematopoietic cells in a manner consistent with the activity of endogenous EPO (Egrie et al 2003).

In a comparative study of rHuEPO and Darbepoetin alfa in vivo, Egrie et al (2003) demonstrated that Darbepoetin alfa has a 3 -fold longer circulating half-life in rats and dogs, and that it is more potent than rHuEPO.

\section{Pharmacokinetics and pharmacodynamics}

Pharmacokinetic studies with Darbepoetin alfa have been completed in a range of patient populations, including healthy volunteers, patients with end-stage renal failure, and with CIA. In those studies in which comparisons to rHuEPO have been done, Darbepoetin alfa was consistently cleared more slowly, with a longer terminal half-life compared with rHuEPO (Allon et al 2002). Pharmacokinetic properties of Darbepoetin alfa administrated subcutaneously were studied in patients receiving chemotherapy every 3 weeks. Peak concentration (median) occurred at 62 and 72 hours postdose, and mean (SD) terminal half-life ranged from 87.7 (26.0) to 60.9 (22.3) hours (Heatherington et al 2001). These studies already suggested that dosing less frequently than the 3-times-weekly doses used for rHuEPO might be effective.

Pharmacokinetics of Darbepoetin alfa also have been studied in function of weight, based on a typical oncology population and with reserve to the weight extremes. Weight did not seem to have an influence on the efficacy of the molecule in a phase II randomized, double-blind study comparing a weight-based versus a fixed dose (Hesketh et al 2004).

\section{Safety}

Darbepoetin alfa is a safe and well-tolerated drug. In all of the clinical studies reported, adverse events were generally associated with malignant disease and the toxic effects of chemotherapy, with no difference between placebo and Darbepoetin alfa arms. The most frequently reported adverse events were gastrointestinal (nausea and vomiting) and constitutional symptoms (fatigue). A broad range of doses and different administration schedules have been studied, with no demonstrated dose-effect relationship for adverse events. Possible thromboembolic complications when using erythropoietic agents are of particular concern. A recently published meta-analysis did not suggest an increased risk (Bohlius, Langensiepen, et al 2005), but an update of that work, now including 57 trials with 9353 patients, reported an increased risk of thromboembolic adverse effects (relative risk [RR] 1.67, 95\% confidence index [CI] 1.35-2.06) (Bohlius, Wilson, et al 2005). Hedenus studied which 
criterion of rise in $\mathrm{Hb}$ during Darbepoetin alfa therapy was the best discriminator between natural $\mathrm{Hb}$ variability and increased risk of thrombotic events (Hedenus, Canon, et al 2005). Three definitions of rapid rise in $\mathrm{Hb}$ were considered $(=2 \mathrm{~g} / \mathrm{dL}$ increase in 28 days; $=1.5 \mathrm{~g} / \mathrm{dL}$ increase in 21 days; and $=1 \mathrm{~g} / \mathrm{dL}$ increase in 14 days). The $2 \mathrm{~g} / \mathrm{dL}$ per 28 days was the best discriminator, while the $1 \mathrm{~g} / \mathrm{dL}$ rule resulted in an excessive rate of "false-positive" risk, even in the absence of erythropoietic therapy. The elucidation of this safety aspect is crucial for the future of eryhropoietic therapy.

One study evaluated fixed dose versus weight-based dose of Darbepoetin alfa and observed no safety problems, with a reservation for the extremes of weight, because of the limited number of these type of patients in the study (Hesketh et al 2004).

Pure red cell aplasia (PRCA) in association with neutralizing antibodies to endogenous EPO has been observed in patients with chronic kidney disease who had been treated by subcutaneous injection of one brand of Epoetin alfa (Eprex) (Casadevall et al 2002; Macdougall 2004). To date, there is no evidence of neutralizing antibodies to Darbepoetin alfa.

An other ongoing safety issue is the exclusion of any adverse effect concerning progression-free or overall survival in patients treated with erythropoietic agents (see "Effect on disease outcome").
Clinical efficacy

Treatment of CIA with Darbepoetin alfa administered once weekly

The clinical efficacy of Darbepoetin alfa once weekly has been established in several phase II and III randomized trials (Table 1).

Glaspy et al (2002) administered Darbepoetin alfa to anemic patients with solid tumors receiving chemotherapy at doses of $0.5 \mu \mathrm{g} / \mathrm{kg}$ to $8.0 \mu \mathrm{g} / \mathrm{kg}$ once a week $(\mathrm{n}=216)$; Epoetin alfa, in an initial dose of $150 \mathrm{U} / \mathrm{kg} 3$ times weekly, with possible dose increase to $300 \mathrm{U} / \mathrm{kg}, 3$ times weekly was the control arm $(n=53)$. There was an evident doseresponse relationship for $\mathrm{Hb}$ response (ie, an increase in $\mathrm{Hb}$ concentration from baseline of at least $2 \mathrm{~g} / \mathrm{dL}$ ) up to doses of $4.5 \mu \mathrm{g} / \mathrm{kg}$. At this dose, $76 \%$ of the patients had a $\mathrm{Hb}$ response (95\% CI 59-94). In a later part of this study, administration of Darbepoetin alfa every 2 weeks proved to result in similar efficacy. In another phase II randomized study, Hedenus et al (2002) evaluated the efficacy of 3 doses of Darbepoetin alfa $(1.0 \mu \mathrm{g} / \mathrm{kg}, 2.25 \mu \mathrm{g} / \mathrm{kg}$, and $4.5 \mu \mathrm{g} / \mathrm{kg})$ $(n=55)$ versus placebo $(n=11)$ in anemic patients with lymphoproliferative malignancies receiving chemotherapy. The proportion of patients achieving $\mathrm{Hb}$ response was higher with any dose of Darbepoetin alfa compared with placebo $(45 \%, 55 \%, 62 \%$ and $10 \%$ for a dose of $1.0 \mu \mathrm{g} / \mathrm{kg}, 2.25 \mu \mathrm{g} /$ $\mathrm{kg}$, and $4.5 \mu \mathrm{g} / \mathrm{kg}$ and placebo respectively; $\mathrm{p}<0.01$ ).

Table I Clinical trials on treatment of chemotherapy-induced anemia with Darbepoetin alfa administered once weekly

\begin{tabular}{|c|c|c|c|c|}
\hline Ref & $\mathbf{n}$ & Study design & Study population & Main results \\
\hline (Glaspy et al 2002) & 269 & $\begin{array}{l}\text { Phase II randomized, open label } \\
\text { Darbepoetin alfa: } 0.5,1.0,1.5,2.25 \text {, } \\
4.5,6.0 \text {, and } 8.0 \mu g / \mathrm{kg} / \text { week } \\
\text { versus } \\
\text { Epoetin alfa: } 1501 \mathrm{U} / \mathrm{kg} 3 \text { times } / \text { week } \\
\text { (increase to } 300 \mathrm{IU} / \mathrm{kg} \text { ) } \\
\text { I2-week treatment }\end{array}$ & $\begin{array}{l}\text { Solid tumors; } \\
\text { receiving chemotherapy; } \\
\mathrm{Hb} \leq 1.0 \mathrm{~g} / \mathrm{dL}\end{array}$ & $\begin{array}{l}\text { Evident dose-response relationship for } \\
\mathrm{Hb} \text { response up to doses of } 4.5 \mu \mathrm{g} / \mathrm{kg}\end{array}$ \\
\hline $\begin{array}{l}\text { (Hedenus et al } \\
\text { 2002) }\end{array}$ & 66 & $\begin{array}{l}\text { Phase II randomized, double-blind } \\
\text { Darbepoetin alfa: I.0, } 2.25 \text {, and } \\
4.5 \mu \mathrm{g} / \mathrm{kg} / \text { week } \\
\text { versus } \\
\text { Placebo: I2-week treatment }\end{array}$ & $\begin{array}{l}\text { Lymphoproliferative } \\
\text { malignancies receiving } \\
\text { chemotherapy; } \\
\mathrm{Hb} \leq \mathrm{I} 1.0 \mathrm{~g} / \mathrm{dL}\end{array}$ & $\begin{array}{l}\text { Proportion of patients achieving } \mathrm{Hb} \\
\text { response is higher with any dose of } \\
\text { Darbepoetin alfa compared with placebo }\end{array}$ \\
\hline $\begin{array}{l}\text { (Vansteenkiste } \\
\text { et al 2002) }\end{array}$ & 314 & $\begin{array}{l}\text { Phase III randomized, double-blind } \\
\text { Darbepoetin alfa: } 2.25 \mu \mathrm{g} / \mathrm{kg} / \text { week } \\
\text { versus } \\
\text { Placebo: 12-week treatment }\end{array}$ & $\begin{array}{l}\text { Lung cancer receiving } \\
\text { platinum-based } \\
\text { chemotherapy; } \\
\mathrm{Hb} \leq \mathrm{I} \text { I g/dL }\end{array}$ & $\begin{array}{l}\text { Significant reduction of incidence of } \\
\text { transfusion and number of units } \\
\text { transfused. } \\
\text { Better hematopoietic response and QoL. }\end{array}$ \\
\hline $\begin{array}{l}\text { (Hedenus et al } \\
\text { 2003) }\end{array}$ & 344 & $\begin{array}{l}\text { Phase III randomized, double-blind } \\
\text { Darbepoetin alfa: } 2.25 \mu \mathrm{g} / \mathrm{kg} / \text { week } \\
\text { versus } \\
\text { Placebo: I2-week treatment }\end{array}$ & $\begin{array}{l}\text { Lymphoproliferative } \\
\text { malignancies receiving } \\
\text { chemotherapy; } \\
\mathrm{Hb} \leq \mathrm{II} \text { g/dL }\end{array}$ & $\begin{array}{l}\text { Significant reduction of } \mathrm{RBC} \text { transfusions } \\
\text { and higher } \mathrm{Hb} \text { response. }\end{array}$ \\
\hline
\end{tabular}

Abbreviations: $\mathrm{Hb}$, hemoglobin; RBC, red blood cells; QoL,quality of life. 
Subsequently, two large, placebo-controlled phase III trials were conducted that confirmed the efficacy of Darbepoetin alfa at a dose of $2.25 \mu \mathrm{g} / \mathrm{kg}$ per week. Vansteenkiste et al (2002) randomly assigned 314 anemic lung cancer patients receiving platinum-containing chemotherapy $(\mathrm{Hb}<11 \mathrm{~g} / \mathrm{dL})$, to either Darbepoetin alfa $(2.25 \mu \mathrm{g} / \mathrm{kg}$ per week) or placebo. Primary endpoint was the proportion of patients who needed red blood cell (RBC) transfusion. There was a statistically significant reduction of both the incidence of transfusion (reduction of $25 \%$ compared with placebo, 95\% CI 14-36, p<0.001) and the number of units transfused (difference of 1.25 units, 95\% CI $0.65-1.84, p<0.001)$. The proportion of patients achieving a hematopoietic response and those with a decrease in fatigue also were significantly in favour of Darbepoetin alfa. Hedenus et al (2003) conducted a similar study in 344 anemic patients with lymphoproliferative malignancies receiving chemotherapy. A significant higher $\mathrm{Hb}$ response (60\% [95\% CI 52-68] achieving a Hb response in the Darbepoetin alfa cohort) and a statistically significant reduction of transfusions $(31 \%$ vs $48 \%, \mathrm{p}<0.001)$ were noted.

The effect of Darbepoetin alfa was also studied in patients with anemia of cancer not treated with chemotherapy (Smith et al 2003). The first open-label part of this trial included 102 patients, who received doses of $0.5 \mu \mathrm{g} / \mathrm{kg}$ to $4.5 \mu \mathrm{g} / \mathrm{kg}$ once weekly for 12 weeks. Hematopoietic response was reached in 70\% (95\% CI 5388 ) at the $2.25 \mu \mathrm{g} / \mathrm{kg}$ dose, and in $100 \%$ at the $4.5 \mu \mathrm{g} / \mathrm{kg}$ dose, both largely superior compared with placebo $(10 \%$, 95\% CI 0-24).

\section{Treatment of CIA with Darbepoetin alfa administered every 3 weeks}

Many chemotherapy schedules for solid tumors are administered in a cycle length of 3 weeks. Therefore, extension of the dosing interval of erythropoietic therapy to once every 3 weeks was considered to be of major interest. Darbepoetin alfa, with its longer serum half-life compared with rHuEPO, was an ideal candidate to explore this option (Table 2).

Kotasek et al (2003) conducted a placebo-controlled, safety and dose-finding study with administration of Darbepoetin alfa every 3 weeks in anemic patients with solid tumors $(\mathrm{n}=249)$. Doses ranged from $4.5 \mu \mathrm{g} / \mathrm{kg}$ to as high as $15 \mu \mathrm{g} / \mathrm{kg}$ in the active arms. Administration of a high dose every 3 weeks proved to be safe. There was a dose-response relationship for $\mathrm{Hb}$ and hematopoietic response up to doses of $12.0 \mu \mathrm{g} / \mathrm{kg}$, and the optimal dose for further development was set at $6.75 \mu \mathrm{g} / \mathrm{kg}$ every 3 weeks.

Synchronous administration of chemotherapy and erythropoietic therapy on an every 3 weeks basis was the most attractive option for both patients and caregivers. Because of the negative historical experience with synchronous use of neutrophil growth factors and chemo(radio)therapy (Bunn et al 1995), similar concerns

Table 2 Clinical trials on treatment of chemotherapy-induced anemia with Darbepoetin alfa administered once every 3 weeks

\begin{tabular}{|c|c|c|c|c|}
\hline Ref & $\mathbf{n}$ & Study design & Study population & Main results \\
\hline (Kotasek et al 2003) & 249 & $\begin{array}{l}\text { Phase II randomized, double-blind } \\
\text { Darbepoetin alfa: } 4.5,6.75,9.0,12.0 \text {, I } \\
3.5 \text {, and I } 5 \mu \mathrm{g} / \mathrm{kg} \text { every } 3 \text { weeks } \\
\text { versus } \\
\text { Placebo: I } 2 \text {-week treatment }\end{array}$ & $\begin{array}{l}\text { Solid tumors receiving } \\
\text { chemotherapy; } \\
\mathrm{Hb} \leq \mathrm{I} 1.0 \mathrm{~g} / \mathrm{dL}\end{array}$ & $\begin{array}{l}\text { Evident dose-response relationship } \\
\text { for hematopoietic response and } \\
\text { mean change in } \mathrm{Hb} \text { up to doses } \\
12.0 \mu \mathrm{g} / \mathrm{kg} \\
\text { Lower percentage of patients } \\
\text { receiving RBC transfusions (any } \\
\text { group) compared with placebo }\end{array}$ \\
\hline (Glaspy et al 2005) & 81 & $\begin{array}{l}\text { Phase II randomized, open label } \\
\text { Darbepoetin alfa } 6.75 \mu \mathrm{g} / \mathrm{kg} \text { every } \\
3 \text { weeks synchronous (day I) } \\
\text { versus } \\
\text { asynchronous (day I5) with } \\
\text { chemotherapy: I6-week treatment }\end{array}$ & $\begin{array}{l}\text { Non myeloid } \\
\text { malignancies receiving } \\
\text { chemotherapy; } \\
\mathrm{Hb} \leq \mathrm{I} \text { I g/dL }\end{array}$ & $\begin{array}{l}\text { Similar mean increase in } \mathrm{Hb} \text { after } \\
6 \text { weeks }\end{array}$ \\
\hline (Canon et al 2006) & 705 & $\begin{array}{l}\text { Phase III randomized, double blind } \\
\text { Darbepoetin alfa } 500 \mu g \text { every } 3 \text { weeks } \\
\text { versus } \\
\text { Darbepoetin alfa } 2.25 \mu \mathrm{g} / \mathrm{kg} \text { every } \\
\text { week: I6-week treatment }\end{array}$ & $\begin{array}{l}\text { Non-myeloid } \\
\text { malignancies receiving } \\
\text { chemotherapy; } \\
\mathrm{Hb} \leq \mathrm{I} \text { I g/dL }\end{array}$ & $\begin{array}{l}\text { Noninferiority of every } 3 \text { weeks } \\
\text { dosing versus every week dosing }\end{array}$ \\
\hline
\end{tabular}

Abbreviations: Hb, hemoglobin; RBC, red blood cells 
were raised about administration of erythropoietic agents on the day when bone marrow precursors were hit by chemotherapy. This important question was addressed in a phase II randomized study (Glaspy et al 2005). As many aspects of pharmacokinetics of endogenous and recombinant human erythropoietin in that setting were not clear, both efficacy and pharmacokinetic parameters were recorded. Patients $(n=81)$ received chemotherapy every three weeks and were randomized 1:1 to receive Darbepoetin alfa $6.75 \mu \mathrm{g} / \mathrm{kg}$ once every three weeks asynchronously (day 15) or synchronously (day 1) with chemotherapy. The primary endpoint (mean increase in $\mathrm{Hb}$ after 6 weeks) was similar in both groups: $1.0 \mathrm{~g} / \mathrm{dL}(95 \%$ : CI 0.6-1.3) asynchronous, $1.0 \mathrm{~g} / \mathrm{dL}(95 \% \mathrm{CI}$ : 0.6-1.5) synchronous $(\mathrm{p}=0.45)$ (Figure $1)$. No significant differences were noted concerning the importance or rate of $\mathrm{Hb}$ change, pointing at similar efficacy of synchronous or asynchronous dosing. The pharmacokinetic data showed an increase of endogenous EPO concentrations in both groups starting 6 hours after chemotherapy and lasting one week. A possible explanation for this phenomenon is a decreased clearance by the bone marrow caused by the myelosuppressive effect of chemotherapy. Synchronous dosing of chemotherapy and Darbepoetin alfa also resulted in an increase in maximal concentration and area under the curve-time curve of Darbepoetin alfa compared with asynchronous dosing. The argument that bone marrow contributes to clearance of erythropoietic proteins is also plausible here. The net result is a higher availability of Darbepoetin alfa on the days when myelosuppression due to chemotherapy is more prominent, resulting in similar efficacy as for asynchronous administration.

The regimen of Darbepoetin alfa every 3 weeks was confirmed in a large phase III study $(n=705)$, that was reported recently (Canon et al 2006). It was a randomized double-blind, double-dummy, active-controlled study conducted in anemic $(\mathrm{Hb}<11 \mathrm{~g} / \mathrm{dl})$ patients with chemotherapy for non-myeloid malignancy, comparing weekly administration of $2.25 \mu \mathrm{g} / \mathrm{kg}$ Darbepoetin alfa versus a fixed dose of $500 \mu \mathrm{g}$ every three weeks. The primary endpoint was the incidence of RBC transfusions from week 5 to the end of treatment. The study had a noninferiority design: the upper limit of the $95 \% \mathrm{CI}$ of the difference in the incidence of RBC transfusions had to be below $12.5 \%$. This number was based on the average difference in transfusion rates of $23 \%$ in the two phase III studies with weekly dosing (Vansteenkiste et al 2002; Hedenus et al 2003). Adjusted for stratification factors, the incidence of transfusions was $19 \%$ (95\% CI 15-24) for the every three weeks and 28\% (95\% CI 23-33) for the every-week group, a difference well below the limit of noninferiority. The validity of Darbepoetin alfa administered every three weeks is further illustrated in Figure 2. The RBC transfusion rates are consistently low in all actively treated groups of four phase III trials with this agent, two placebo-controlled ones (Vansteenkiste et al 2002; Hedenus et al 2003), one with front-loaded dosing (Kotasek et al 2004), and the every 3 weeks study (Canon et al 2006).

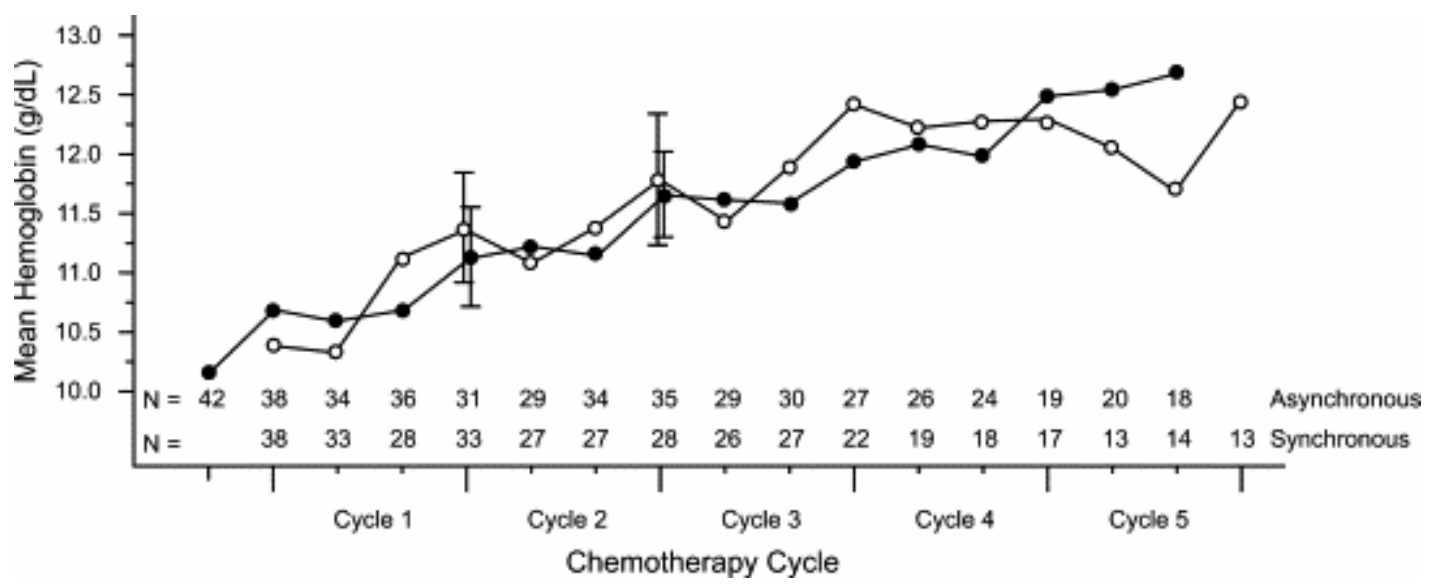

Figure I Mean hemoglobin over time by chemotherapy cycle in the phase II randomized study with asynchronous (filled circles) or synchronous administration (empty circles) of Darbepoetin alfa administered every 3 weeks. Error bars represent $95 \%$ confidence limits. Copyright $@ 2005$. Reproduced with permission from Glaspy J, Henry D, Patel R, et al. 2005. Effects of chemotherapy on endogenous erythropoietin levels and the pharmacokinetics and erythropoietic response of darbepoetin alfa: a randomised clinical trial of synchronous versus asynchronous dosing of darbepoetin alfa. Eur J Cancer, 4I:I।40-9. 


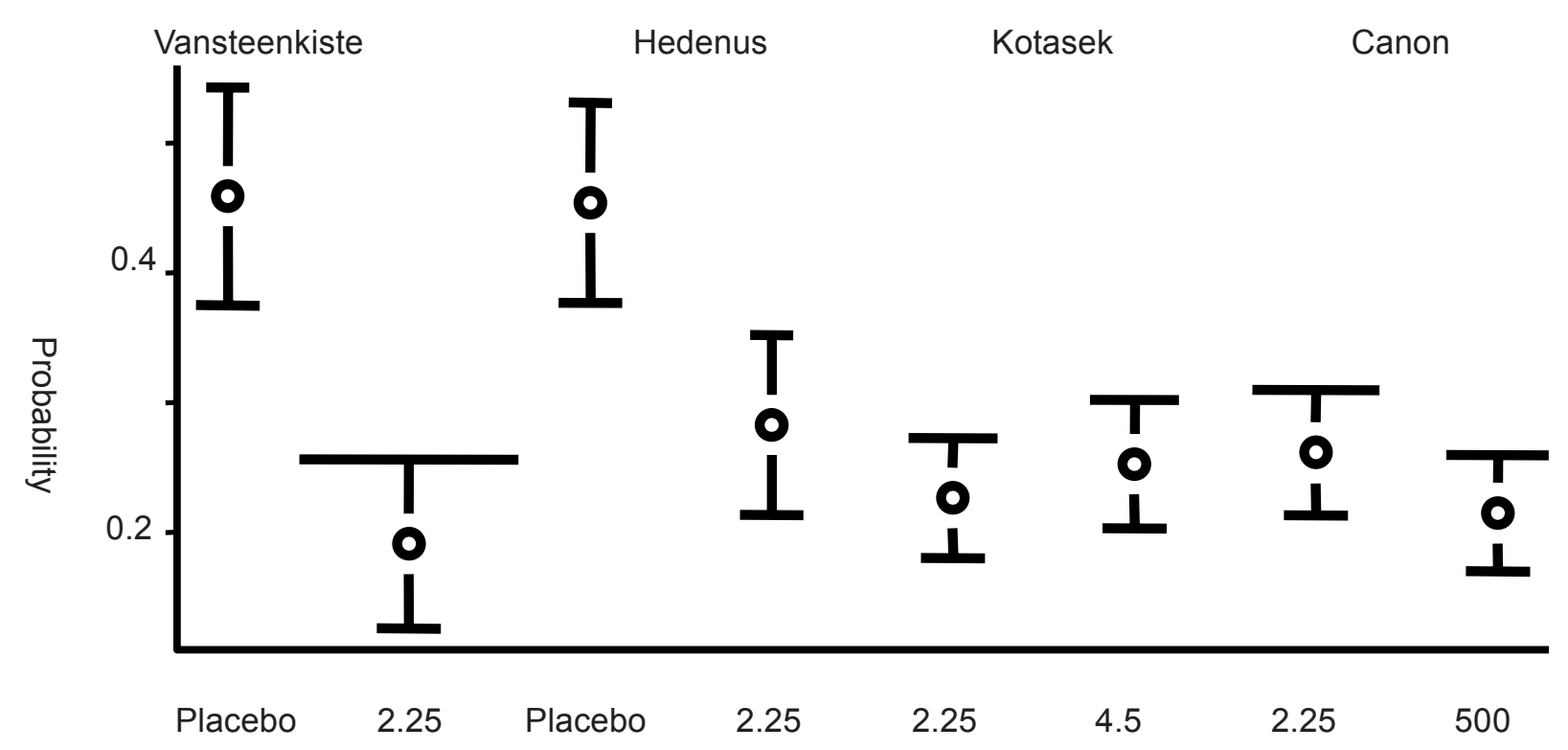

Figure 2 Red blood cell transfusion rates in four phase III trials with Darbepoetin alfa. Data from two placebo-controlled studies (Vansteenkiste et al 2002; Hedenus et al 2003), the front-loading study (Kotasek et al 2004), and the every 3 weeks dosing study (Canon et al 2006).

\section{Clinical trials on treatment of $\mathrm{CIA}$ with Darbepoetin alfa focusing on special issues}

\section{Front-loaded dosing}

Another attractive hypothesis to improve the efficacy of erythropoietic therapy has been the front-loading approach with the purpose of achieving an optimal and fast response. This would also permit to identify non-responders early. Therapy was started with a dose-intense schedule during a correction phase (the time needed to reach a $\mathrm{Hb}$ value of $\geq 12 \mathrm{~g} / \mathrm{dL}$ ) with the intent to decrease the dose or increase the dose interval during a maintenance phase (Table 3).

Two phase II trials explored this concept. In a randomized, active-controlled pilot trial $(\mathrm{n}=127)$ by Glaspy et al (2003), patients were randomly assigned to 1 of 4 treatment groups for a duration of 12 weeks. In the active control arm, patients received $40000 \mathrm{U}$ rHuEPO per week, with escalation to $60000 \mathrm{U}$ per week for non-responders. The Darbepoetin alfa arms were at doses of $4.5 \mu \mathrm{g} / \mathrm{kg}$ per week until $\mathrm{Hb}$ concentration was $\geq 12 \mathrm{~g} / \mathrm{dL}$, then $1.5 \mu \mathrm{g} / \mathrm{kg}$ per week (group 1), $4.5 \mu \mathrm{g} / \mathrm{kg}$ per week for 4 weeks, followed by $2.25 \mu \mathrm{g} / \mathrm{kg}$ per week for 8 weeks (group 2) or $3.0 \mu \mathrm{g} / \mathrm{kg}$ every 2 weeks (group 3). A marked increase of the $\mathrm{Hb}$ level was observed early in the treatment period (week 5) for all the front-loaded regimens. Median time to $\mathrm{Hb}$ response was 50 days for 2 of the 3 groups treated with Darbepoetin alfa. The proportion of patients achieving $\mathrm{Hb}$ response varied from $58 \%$ to $65 \%$ over the 3 Darbepoetin alfa groups. The limited number of patients permitted not to make final conclusions concerning efficacy endpoints but the data were encouraging. Another open label, phase II randomized study by Hesketh et al (2004) was promising as well. In a front-loaded schedule, 243 patients received Darbepoetin alfa every week during the correction phase (ie, the phase until a $\mathrm{Hb}$ concentration $\geq 12 \mathrm{~g} / \mathrm{dL}$ was achieved without a RBC transfusion in the previous 4 weeks) followed by an administration every 3 weeks during the maintenance phase (ie, until week 16). Patients were divided into a group receiving a fixed-dose $(325 \mu \mathrm{g})$ and a group receiving a weight-based dose $(4.5 \mu \mathrm{g} / \mathrm{kg})$ of Darbepoetin alfa. Almost $80 \%$ of the patients achieved $\mathrm{Hb}$ correction in both groups. Median time to correction was 42 days, identical for both groups.

These promising findings were further explored in a large double-blind, double-dummy, randomized phase III study in 727 patients with non-myeloid malignancies and CIA ( $\mathrm{Hb}$ $\leq 11 \mathrm{~g} / \mathrm{dL}$ ) (Kotasek et al 2004). The expected advantage of front-loaded dosing could not be confirmed. Patients were treated with either Darbepoetin alfa $4.5 \mu \mathrm{g} / \mathrm{kg}$ per week for 4 weeks, followed by maintenance with $4.5 \mu \mathrm{g} / \mathrm{kg}$ every 3 weeks, or Darbepoetin alfa $2.25 \mu \mathrm{g} / \mathrm{kg}$ per week, for an interval of 16 weeks. The primary aim of the study was to prove noninferiority to standard weekly dosing by evaluating the number of transfusions. No difference in number of transfusions from week 5 to the end of treatment was seen 
between both groups: $24 \%$ (95\% CI 19-28) for the $2.25 \mu \mathrm{g} /$ $\mathrm{kg}$ every-week group versus $25 \%$ (95\% CI 20-30) for the front-loaded group. The hematopoietic response level was higher when Darbepoetin alfa was administered every week (87\%, 95\% CI 83-91) compared with the correction/ maintenance approach $(68 \%, 62-73)$. In conclusion, frontloading using this administration schedule of Darbepoetin alfa was of no additional benefit compared with standard therapy, taken in account that standard therapy appeared to be very efficient.

\section{Subcutaneous versus intravenous administration}

To make Darbepoetin alfa therapy still more convenient, especially for patients with central venous access, the efficacy of intravenous administration has been studied (Table 3). A total of 120 anemic patients with non-myeloid malignancies planned to receive 12 additional weeks of chemotherapy, were randomly assigned (1:1 allocation) to subcutaneous or intravenous administration (Justice et al 2005). During a correction phase lasting from week 1 to 6 , each group received Darbepoetin alfa $4.5 \mu \mathrm{g} / \mathrm{kg}$ weekly, followed by a less frequent dose of $4.5 \mu \mathrm{g} / \mathrm{kg}$ every 3 weeks during a maintenance phase (until week 15). Primary endpoint was the change in $\mathrm{Hb}$ from baseline. The mean change in $\mathrm{Hb}$ (intention-to-treat) was $1.0 \mathrm{~g} / \mathrm{dL}$ (95\% CI 0.6$1.4)$ in the intravenous group and $1.4 \mathrm{~g} / \mathrm{dL}(95 \% \mathrm{CI} 1.0$ 1.9) in the subcutaneous group. This difference between both groups was not statistically significant. Results for other endpoints such as hematopoietic response and number of $\mathrm{RBC}$ transfusions were similar as well. Pharmacokinetic analyses showed no accumulation of Darbepoetin alfa, even not during the correction phase. Efficacy is similar considering both ways of administration.

\section{Future issues with Darbepoetin alfa therapy Iron supplementation}

Another open question in the treatment of CIA is the role of iron supplementation. When plasma iron values and iron reserve values are low (saturation $<20 \%$ ), iron substitution seems attractive. Whether oral or intravenous iron has to be preferred remains unsolved. Intravenous iron improves $\mathrm{Hb}$ response and decreases dosage requirements in patients with anemia of kidney disease, but its effect is less documented in cancer patients.

In a prospective, multicenter, open-label, randomized trial, Auerbach et al (2004) studied 157 patients with chemotherapy-related anemia $(\mathrm{Hb}<10.5 \mathrm{~g} / \mathrm{dL})$ receiving rHuEPO $40000 \mathrm{U}$ once weekly with either no iron, oral iron $325 \mathrm{mg}$ twice daily, or iron dextran intravenously. Mean $\mathrm{Hb}$ increase was significantly better with intravenous iron than with no or oral iron. The hematopoietic response was $68 \%$ with intravenous iron, compared with $36 \%$ with oral iron, and $25 \%$ without iron. The interpretation of these findings is difficult, as the very low hematopoietic response in the cohorts with oral or no iron is not in line with any other study with erythropoietic agents. This suggests inclusion of a special selection of patients, probably those with severe iron deficiency, as one of the inclusion criteria of the trial was an iron saturation below 19\%.

A study in a less selected group of patients receiving chemotherapy is ongoing. The hematopoietic response after 16 weeks of treatment with $500 \mu \mathrm{g}$ of Darbepoetin alfa every three weeks with either intravenous iron versus oral or no iron supplementation according to local practice will be compared. This study will hopefully lead to a better understanding of the iron issue.

\section{Effect on disease outcome}

The positive effect of the treatment of anemia on healthrelated QoL is well established. It is also clear that anemia is an independent negative prognostic factor, with growing evidence for other consequences of anemia in patients with cancer such as increased resistance to therapy, increased tumor invasiveness, and metastatic potential, resulting in reduced survival (Caro et al 2001).

The question of whether correction of anemia during oncological treatment can favourably influence outcome, however, remains unresolved at the moment. Encouraging findings in this respect were present in recent randomized trials. In our phase III study, the hypothesis of a potentially better survival in patients with small cell lung cancer treated with Darbepoetin alfa versus those receiving placebo was generated (Vansteenkiste et al 2002). A possible relationship between increased $\mathrm{Hb}$ and better survival was also reported in a phase III study on 375 anemic $(\mathrm{Hb}<10.5 \mathrm{~g} / \mathrm{dL})$ patients with solid or nonmyeloid hematological malignancies treated with non-platinum chemotherapy (Littlewood et al 2001). A similar, but also nonsignificant, trend towards improved survival with rHuEPO was observed in another placebocontrolled study (Witzig et al 2004). 
On the other hand, caution was raised recently, following two studies with rHuEPO in breast cancer and head and neck cancer reporting negative survival results. The first one was a placebo-controlled study in patients with metastatic breast cancer that was prematurely stopped because of a statistically significant higher mortality in the Epoetin alfa group (Leyland-Jones et al 2005). There was an excess mortality during the first 4 months of treatment, due to an increased incidence of both tumor progression as well as thrombotic vascular events. After the initial excess in deaths in the active arm, overall time to progression was similar in both arms. No definitive conclusions can be made regarding tumor progression rates, however, because of the lack of data on many potentially important prognostic factors that might have affected study outcome. External review by an independent group of researchers even suggested worse prognostic features for the Epoetin alfa group in terms of age, performance status, disease extent, degree of baseline anemia, and thromboembolic risk.

The second study was a randomized double-blind placebo-controlled study including 351 anemic patients with head and neck cancer (Henke et al 2003). Locoregional progression-free survival (the primary endpoint) was worse with Epoetin beta than with placebo (adjusted RR 1.62, 95\% CI 1.22-2.14, $\mathrm{p}=0.0008)$. The study has been criticized for several reasons. First, there were potential imbalances in study populations across arms, as there were more smokers (with possibly increased co-morbidity) and relapsed patients in the Epoetin beta arm, and as no data on performance status were available. Second, protocol violations were present in $36 \%$ of the patients, and the difference in outcome

Table 3 Clinical trials on treatment of chemotherapy-induced anemia with Darbepoetin alfa focusing on special issues

\begin{tabular}{|c|c|c|c|c|}
\hline Ref & n & Study design & $\begin{array}{l}\text { Study } \\
\text { population }\end{array}$ & Main results \\
\hline \multicolumn{5}{|l|}{ Front-loaded dosing } \\
\hline (Glaspy et al 2003) & 127 & $\begin{array}{l}\text { Phase II randomized, double-blind } \\
\text { Darbepoetin alfa : } 4.5 \mu \mathrm{g} / \mathrm{kg} / \text { week } \\
\text { until } \mathrm{Hgb}=12 \mathrm{~g} / \mathrm{dL} \text {, then } \\
\text { I.5 } \mathrm{gg} / \mathrm{kg} / \text { week (Group I) } \\
4.5 \mu \mathrm{g} / \mathrm{kg} / \text { week for } 4 \text { weeks, then } \\
2.25 \mu \mathrm{g} / \mathrm{kg} / \text { week (Group 2) } \\
4.5 \mu \mathrm{g} / \mathrm{kg} / \text { week for } 4 \text { weeks, then } \\
3.0 \mu \mathrm{g} / \mathrm{kg} \text { every } 2 \text { weeks (Group 3) } \\
\text { versus } \\
\text { rHuEPO } 40000 \mathrm{U} / \text { week (increase } \\
\text { to } 60000 \mathrm{U} / \text { week): I2-week treatment }\end{array}$ & $\begin{array}{l}\text { Solid tumors } \\
\text { receiving } \\
\text { chemotherapy; } \\
\mathrm{Hb} \leq \mathrm{I} \text { I g/dL }\end{array}$ & $\begin{array}{l}\text { Safe and effective improvement of } \mathrm{Hb} \\
\text { concentration }\end{array}$ \\
\hline (Hesketh et al 2004) & 243 & $\begin{array}{l}\text { Phase II randomized, double-blind } \\
\text { Darbepoetin alfa fixed dose } \\
(325 \mu \mathrm{g} / \text { week) } \\
\text { versus } \\
\text { Darbepoetin alfa weight-based dose } \\
(4.5 \mu \mathrm{g} / \mathrm{kg} / \text { week), until Hb = } 12.0 \mathrm{~g} / \mathrm{dL} \text {, } \\
\text { followed by administration every } \\
3 \text { weeks: I6-week treatment }\end{array}$ & $\begin{array}{l}\text { Non-myeloid } \\
\text { malignancies, } \\
\text { receiving } \\
\text { chemotherapy; } \\
\text { Hb } \leq \mathrm{I} \text { I.0 g/dL }\end{array}$ & $\begin{array}{l}\text { High hematopoietic response in both the } \\
\text { fixed-dose group ( } 86 \% \text { ) and weight-based } \\
\text { dose group ( } 84 \%) \text {. Similar median time to } \\
\text { hematopoietic response. } \\
\text { Hb concentrations maintained at target } \\
\text { levels for up to } 16 \text { weeks in both groups }\end{array}$ \\
\hline (Kotasek et al 2004) & 727 & $\begin{array}{l}\text { Phase III randomized, double-blind, } \\
\text { active-controlled } \\
\text { Darbepoetin alfa } 2.25 \mu \mathrm{g} / \mathrm{kg} / \text { week } \\
\text { versus } \\
\text { Darbepoetin alfa } 4.5 \mu \mathrm{g} / \mathrm{kg} / \text { week for } \\
4 \text { weeks, then } 4.5 \mu \mathrm{g} / \mathrm{kg} \text { every } 3 \text { weeks }\end{array}$ & $\begin{array}{l}\text { Non-myeloid } \\
\text { malignancies, } \\
\text { receiving } \\
\text { chemotherapy; } \\
\text { Hb } \leq \mathrm{I} \text { I.0 g/dL }\end{array}$ & $\begin{array}{l}\text { Noninferiority of front-loading compared with } \\
\text { standard weekly dosing } \\
\text { Better hematopoietic response in standard } \\
\text { weekly dosing }\end{array}$ \\
\hline \multicolumn{5}{|c|}{ Subcutaneous versus intravenous administration } \\
\hline (Justice et al 2005) & 118 & $\begin{array}{l}\text { Phase II randomized, open label } \\
\text { Darbepoetin alfa } 4.5 \mu \mathrm{g} / \mathrm{kg} \text { for } 6 \text { weeks, } \\
\text { followed by } 4.5 \mu \mathrm{g} / \mathrm{kg} \text { every } 3 \text { weeks for } \\
\text { I } 2 \text { weeks subcutaneous } \\
\text { versus } \\
\text { Same schedule intravenous } \\
\text { I8-week treatment }\end{array}$ & $\begin{array}{l}\text { Non-myeloid } \\
\text { malignancies, } \\
\text { receiving } \\
\text { chemotherapy; } \\
\text { Hb } \leq \mathrm{I} \text { I.0 g/dL }\end{array}$ & $\begin{array}{l}\text { Equal efficacy of Darbepoetin alfa administered } \\
\text { IV or SC }\end{array}$ \\
\hline
\end{tabular}

Abbreviations: Hb, hemoglobin; IV, intravenous; SC, subcutaneous. 


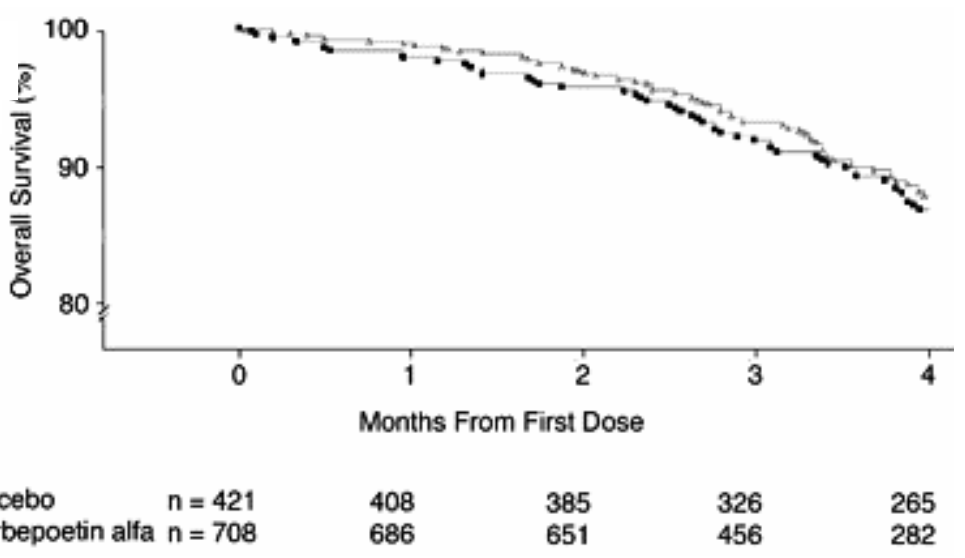

Figure 3 Combined analysis of survival from four Darbepoetin alfa studies in chemotherapy-induced anemia.

was no longer significant when the analysis was restricted to the as-per-protocol treated patients. Third, the $\mathrm{Hb}$ ranges were far above those usually reported in other studies on erythropoietic agents: treatment changes were to be made only if $\mathrm{Hb}$ values exceeded $14 \mathrm{~g} / \mathrm{dL}$ in women or $15 \mathrm{~g} / \mathrm{dL}$ in men, or when $\mathrm{Hb}$ increased more than $2 \mathrm{~g} / \mathrm{dL}$ in one week. The mean $\mathrm{Hb}$ concentration at 4 weeks in this cancer population was $14.8 \mathrm{~g} / \mathrm{dL}$.

The results of these two studies (Henke et al 2003; Leyland-Jones et al 2005) are in contrast with previous trials (Littlewood et al 2001; Vansteenkiste et al 2002; Witzig et al 2004), and with the conclusion of a published metaanalysis based on 27 trials involving 3287 adult patients. Overall, there was a slightly more favourable meta-analytic survival outcome in the erythropoietin-treated patients (hazard ratio [HR] $0.81,95 \%$ CI $0.67-0.99$ ). This metaanalysis has been updated recently. The study now concerns 57 trials with 9353 patients, including the two trials with negative impact on survival. Positive results on reduced risk of transfusion and presence of hematological response were maintained. The incidence of thromboembolic complications was increased (as mentioned in "Safety"). As for survival, the initially suggested possible benefits did no longer hold true (HR 1.08; 95\% CI 0.99-1.18; 42 trials, $\mathrm{n}=8167)$. The authors tried to explain the change in conclusion by pointing at possible factors such as thromboembolic complications, tumor progression issues, but also the methodological limitations of some studies. As a whole, the evidence confirms the value of erythropoietic therapy in reducing transfusions and improving QoL in established indications such as CIA, but further elucidation of the effect of erythropoietic therapy when used to obtain high-normal $\mathrm{Hb}$ values in an attempt to improve outcome is clearly needed.
It should also be noted that no similar problems with Darbepoetin alfa have occurred. In a recent combined analysis of four studies, including the two randomized, double-blind, placebo-controlled phase III studies of weekly dosing of Darbepoetin alfa, the prospectively defined shortand long-term progression-free and overall survival endpoints were not different across arms (HR 0.92; 95\% CI $0.78-1.07$; 0.95; 95\% CI 0.78-1.16, respectively) (Figure 3) (Hedenus, Vansteenkiste, et al 2005). Different erythropoietic proteins such as Epoetin alfa or beta or Darbepoetin alfa have unique pharmacokinetics, and this may be accompanied by distinct effects on survival. The dose and schedule of erythropoietic therapy may also be important, as well as the chosen target $\mathrm{Hb}$ to act on survival. Several ongoing placebo-controlled trials with Darbepoetin alfa in different tumor types are studying these important questions.

\section{Conclusion}

Anemia is frequent in cancer patients with chemotherapy, and has an important negative effect on health-related QoL. Darbepoetin alfa, the first of a novel generation of erythropoietic agents, has been confirmed to be effective when administered once weekly at a dose of $2.25 \mu \mathrm{g} / \mathrm{kg}$ in two large phase III placebo-controlled trials in patients with solid tumors and hematological malignancies. Furthermore, it was a safe and well tolerated drug. More recently, different other issues have been studied. Front-loaded dosing was explored to accelerate the $\mathrm{Hb}$ response and effect on QoL. Phase II data were promising, but no benefit compared with standard dosing could be shown in a large phase III study.

In an attempt to further increase convenience for patients and caregivers, extending the dose interval to every three 
weeks and thereby adapting the dose frequency to the most common chemotherapy schedules was studied. In a large phase III trial, administration of $500 \mu \mathrm{g}$ every 3 weeks was not inferior to the weekly dosing, both in reduction of $\mathrm{RBC}$ transfusion, $\mathrm{Hb}$ parameters, and QoL. This clinically attractive schedule has been approved by the European Agency for the Evaluation of Medicinal Products (EMEA) and approval by the Food and Drug Administration (FDA) is pending. When using Darbepoetin alfa every 3 weeks, efficacy is similar when Darbepoetin alfa is administered synchronous or asynchronous with chemotherapy. For daily practice it is obvious that administration on the same day just prior to the chemotherapy is preferred.

Issues for future study are the optimal iron supplementation strategy and the effect of erythropoietic therapy on outcome. The last issue is a hot topic, especially after recent negative results of two outcome studies with rHuEPO that targeted normal to high $\mathrm{Hb}$ levels. No final conclusions can be made, as these two studies had methodological flaws and are in conflict with other studies. The influence of erythropoietic therapy on outcome remains a very attractive field of investigation, and the results of ongoing survival studies are eagerly awaited.

\section{Acknowledgments}

Johan Vansteenkiste is holder of the Amgen Fund in Supportive Care at the Catholic University of Leuven, Belgium.

\section{References}

Allon M, Kleinman K, Walczyk M, et al. 2002. Pharmacokinetics and pharmacodynamics of darbepoetin alfa and epoetin in patients undergoing dialysis. Clin Pharmacol Ther, 72:546-55.

Auerbach M, Ballard H, Trout JR, et al. 2004. Intravenous iron optimizes the response to recombinant human erythropoietin in cancer patients with chemotherapy-related anemia: a multicenter, open-label, randomized trial. J Clin Oncol, 22:1301-7.

Bohlius J, Langensiepen S, Schwarzer G, et al. 2005. Recombinant human erythropoietin and overall survival in cancer patients: results of a comprehensive meta-analysis. J Natl Cancer Inst, 97:489-98.

Bohlius J, Wilson J, Bayliss S, et al. 2005. Epoetin and Darbepoetin to treat cancer patients: Updated meta-analysis results [abstract]. Blood, 106:751.

Bunn PA, Crowley J, Kelly K, et al. 1995. Chemoradiotherapy with or without granulocyte-macrophage colony-stimulating factor in the treatment of limited-stage small cell lung cancer: a prospective phase III randomized study of the Southwest Oncology Group. J Clin Oncol, $13: 1632-41$.

Canon JL, Vansteenkiste J, Bodoky G, et al. 2006. Randomized, double blind, active-controlled trial of every-3-week Darbepoetin alfa for the treatment of chemotherapy-induced anemia. J Natl Cancer Inst, 98:273-84.
Caro JJ, Salas M, Ward A et al. 2001. Anemia as an independent prognostic factor for survival in patients with cancer: a systemic, quantitative review. Cancer, 91:2214-21.

Casadevall N, Nataf J, Viron B, et al. 2002. Pure red-cell aplasia and antierythropoietin antibodies in patients treated with recombinant erythropoietin. N Engl J Med, 346:469-75.

Cascinu S, Fedeli A, Del Ferro E, et al. 1994. Recombinant human erythropoietin treatment in cisplatin-associated anemia: a randomized, double-blind trial with placebo. J Clin Oncol, 12:1058-62.

Curt GA. 2000. Impact of fatigue on quality of life in oncology patients. Semin Hematol, 37(Suppl 6): 14S-7S.

Curt GA, Breitbart W, Cella D, et al. 2000. Impact of cancer-related fatigue on the lives of patients: new findings from the Fatigue Coalition. Oncologist, 5:353-60.

Darling RJ, Kuchibhotla U, Glaesner W, et al. 2002. Glycosylation of erythropoietin affects receptor binding kinetics: role of electrostatic interactions. Biochemistry, 41:14524-31.

Egrie JC, Dwyer E, Browne JK, et al. 2003. Darbepoetin alfa has a longer circulating half-life and greater in vivo potency than recombinant human erythropoietin. Exp Hematol, 31:290-9.

Eschbach JW, Egrie JC, Downing MR, et al. 1987. Correction of the anemia of end-stage renal disease with recombinant human erythropoietin. Results of a combined phase I and II clinical trial. $N$ Engl $J$ Med, 316:73-8.

Eschbach JW, Abdulhadi MH, Browne JK, et al. 1989. Recombinant human erythropoietin in anemic patients with end-stage renal disease. Results of a phase III multicenter clinical trial. Ann Intern Med, 111:9921000.

Glaspy J, Henry D, Patel R, et al. 2005. Effects of chemotherapy on endogenous erythropoietin levels and the pharmacokinetics and erythropoietic response of darbepoetin alfa: a randomised clinical trial of synchronous versus asynchronous dosing of darbepoetin alfa. Eur J Cancer, 41:1140-9.

Glaspy JA, Jadeja JS, Justice G, et al. 2002. Darbepoetin alfa given every 1 or 2 weeks alleviates anemia associated with cancer chemotherapy. Br J Cancer, 87:268-76.

Glaspy JA, Jadeja JS, Justice G, et al. 2003. A randomized, active-control, pilot trial of front-loaded dosing regimens of darbepoetin-alfa for the treatment of patients with anemia during chemotherapy for malignant disease. Cancer, 97:1312-20.

Heatherington AC, Schuller J, Mercer AJ. 2001. Pharmacokinetics of novel erythropoiesis stimulating protein (NESP) in cancer patients: preliminary report. Br J Cancer, 84(Suppl 1):11-16.

Hedenus M, Hansen S, Taylor K, et al. 2002. Randomized, dose-finding study of darbepoetin alfa in anemic patients with lymphoproliferative malignancies. Br J Haematol, 119:79-86.

Hedenus M, Adriansson M, San Miguel J, et al. 2003. Efficacy and safety of darbepoetin alfa in anemic patients with lymphoproliferative malignancies: a randomized, double-blind, placebo-controlled study. Br J Haematol, 122:394-403.

Hedenus M, Canon JL, Kotasek D, et al. 2005. Effects of dose adjustment rules on safety during erythropoietic therapy: A retrospective analysis of Darbepoetin alfa administered either every 3 weeks or weekly [abstract]. Blood, 106:3376.

Hedenus M, Vansteenkiste J, Kotasek D, et al. 2005. Darbepoetin alfa for the treatment of chemotherapy-induced anemia: disease progression and survival analysis from 4 randomized, double-blind, placebocontrolled trials. J Clin Oncol, 23:6941-8.

Henke M, Laszig R, Rube C, et al. 2003. Erythropoietin to treat head and neck cancer patients with anemia undergoing radiotherapy: randomised, double-blind, placebo-controlled trial. Lancet, 362:125560.

Hesketh PJ, Arena F, Patel D, et al. 2004. A randomized controlled trial of darbepoetin alfa administered as a fixed or weight-based dose using a front-loading schedule in patients with anemia who have nonmyeloid malignancies. Cancer, 100:859-68. 
Justice G, Kessler JF, Jadeja J, et al. 2005. A randomized, multicenter study of subcutaneous and intravenous darbepoetin alfa for the treatment of chemotherapy-induced anemia. Ann Oncol, 16:1192-8.

Kotasek D, Steger G, Faught W, et al. 2003. Darbepoetin alfa administered every 3 weeks alleviates anemia in patients with solid tumors receiving chemotherapy; results of a double-blind, placebo-controlled, randomised study. Eur J Cancer, 39:2026-34.

Kotasek D, Canon JL, San Miguel J, et al. 2004. Correction/maintenance dosing (front loading) of darbepoetin alfa: final results from a randomized phase 3 active controlled trial [abstract]. Blood, 104:455A.

Leyland-Jones B, Semiglazov V, Pawlicki M, et al. 2005. Maintaining normal hemoglobin levels with epoetin alfa in mainly nonanemic patients with metastatic breast cancer receiving first-line chemotherapy: a survival study. J Clin Oncol, 23:5960-72.

Lin FK, Suggs S, Lin CH, et al. 1985. Cloning and expression of the human erythropoietin gene. Proc Nat Acad Science U S A, 82:7580-4.
Littlewood TJ, Bajetta E, Nortier JW, et al. 2001. Effects of epoetin alfa on hematologic parameters and quality of life in cancer patients receiving nonplatinum chemotherapy: results of a randomized, doubleblind, placebo-controlled trial. J Clin Oncol, 19:2865-74.

Macdougall IC. 2004. Pure red cell aplasia with anti-erythropoietin antibodies occurs more commonly with one formulation of epoetin alfa than another. Curr Med Res Opin, 20:83-6.

Smith RE, Tchekmedyian NS, Chan D, et al. 2003. A dose- and schedulefinding study of darbepoetin alpha for the treatment of chronic anemia of cancer. Br J Cancer, 88:1851-8.

Vansteenkiste J, Pirker R, Massuti B, et al. 2002. Double-blind, placebocontrolled, randomized phase III trial of darbepoetin alfa in lung cancer patients receiving chemotherapy. J Natl Cancer Inst, 94:1211-20.

Witzig TE, Silberstein PT, Loprinzi CL, et al. 2004. Phase III, randomized, double-blind study of epoetin alfa compared with placebo in anemic patients receiving chemotherapy. J Clin Oncol, 22:2606-17. 
